Шайманова Ксения Александровна,

магистрант, ФГБОУ ВО «Ангарский государственный технический университет», e-mail: Rudacov@yandex.ru

Усов Константин Ильич, доцент, ФГБОУ ВО «Ангарский государственный технический университет», e-mail: konstausov@yandex.ru

СООТВЕТСТВИЕ ФАКТИЧЕСКИХ УСЛОВИЙ ТРУДА ЭЛЕКТРОГАЗОСВАРЩИКА РУЧНОЙ ДУГОВОЙ СВАРКИ 5 РАЗРЯДА С ТРЕБУЕМЫМИ НОРМАТИВАМИ ПОКАЗАТЕЛЕЙ

Shaymanova K.A, Usov K.I.

\title{
CONFORMITY OF THE ACTUAL WORKING CONDITIONS OF THE ELECTRIC GAS WELDING MACHINE OF MANUAL ARC WELDING OF 5 DISCHARGE WITH THE REQUIRED NORMALS OF INDICATORS
}

Аннотация. В статье рассмотрено соответствие фактических условий труда с нормативными показателями для рабочего места электрогазосварщика.

Ключевые слова: газоэлектросварщик, условия труда, норматив, показатель, класс условий труда.

Abstract. The article considers the correspondence of the actual working conditions with the normative indicators for the workplace of the electric gas welder.

Keywords: gas electric welder, working conditions, standard, indicator, class of working conditions.

Согласно штатному расписанию в организации ООО «Олимп», занимающейся строительно-монтажными работами, имеется три рабочих места электрогазосварщика ручной дуговой сварки 5-го разряда [1]. Профессиональными компетенциями электрогазосварщика 5-го разряда являются: знание электрических схем и конструкций различных типов сварочных машин; технологических свойств свариваемых металлов, а также металла, наплавленного электродами различных марок и отливок, подвергающихся строганию; технологии сварки ответственных изделий в камерах с контролируемой атмосферой.

Проанализировав данные специальной оценки условий труда, которая проводилась с 1 по 8 июля 2016 года можно сделать следующие выводы:

1) Концентрация дижелезотриоксида и марганца составляют $7,49 \mathrm{mr} / \mathrm{m}^{3}$ что, превышает предельно допустимое значение $6 \mathrm{mr} / \mathrm{M}^{3}$ [3], а это значит, что по химическому фактору производственной среды и трудового процесса, класс условий труда электрогазосварщика соответствует классу 3.1 [3].

2) По показателю шума профессию электрогазосварщика можно отнести ко 2 классу условий труда, так как уровень шума составляет 68,6 дБА и не превышает оптимальные гигиенические нормативы [4]. Организм работника восстанавливается после отдыха или к выходу на следующую смену. При этом не отмечается существенных функциональных изменений в организме ни в конкретно взятый момент, ни в ближайшей или отдаленной перспективе. 
3) Условия труда по показателям световой среды относятся к классу 3.1 [4], так как присутствует прямая блескость. Контроль данного фактора, вызывающего неприятные ощущения при неравномерном распределении яркостей в поле зрения, производится визуально.

4) По фрактору ультрафиолетового излучения производственной среды и трудового процесса, класс условий труда электрогазосварщика соответствует классу 3.1. Интенсивность ультрафиолетового излучения (УФ-В, УФ-С, УФ-В + УФ-С) в несколько раз превышает предельно допустимые значения [4]. Критическими органами для восприятия УФИ являются кожа и глаза: воздействие УФИ может вызвать в них специфические изменения.

5) По фрактору тяжести трудового процесса, класс условий труда электрогазосварщика соответствует классу 3.1 [5]. Необходимо разработать меры, направленные на снижение удельного веса физического труда, помимо этого, нужно серьезное внимание уделить мерам по снижению утомления во время выполнения локальной мышечной работы.

\section{ЛИТЕРАТУРА}

1. Устав общества с ограниченной ответственностью «Олимп».

2. Нормативные документы о проведении специальной оценки условий труда (договора, общие положения, инструкции).

3. ГН 2.2.5.686-98 «Предельно допустимые концентрации (ПДК) вредных веществ в воздухе рабочей зоны. Гигиенические нормативы».

4. Санитарно-эпидемиологические правила и нормативы СанПиН 2.2.4.3359-16 «Санитарно-эпидемиологические требования к физическим фракторам на рабочих местах».

5. Руководство Р 2.2.2006-05 «Руководство по гигиенической оценке факторов рабочей среды и трудового процесса. Критерии и классификации условий труда» (утв. Главным государственным санитарным врачом РФ 29 июля 2005 г.) 